\title{
Foliar supplementation with micronutrients during early growth of bitter gourd fruit (Momordica charantia) augments resistance to melon fly (Bactrocera cucurbitae) infestation by activation of antioxidant system
}

\section{Seshadri Shivashankar and Manoharan Sumathi}

Division of Plant Physiology and Biochemistry, ICAR-Indian Institute of Horticultural Research, Hesaraghatta Lake P.O., Bengaluru 560089. Karnataka, India

Received: 21 Jan. 2020/Accepted 15 April 2020 / Publication date: 30 April 2020

\begin{abstract}
Melon fly is the most destructive pest of cucurbits all over the world. Although, the pest is controlled by the use of insecticides, the risks of development of resistance in the pest due to continued application of pesticide and accumulation of toxic residues in fruits have led to the search for alternative non-chemical control strategies which are eco-safe and environment friendly. In this study, an attempt was made to examine the effect of foliar mineral nutrition on pest incidence and fruit quality. The field study was laid out in a Randomized complete block design in which bitter gourd fruits during the early fruit development phase were sprayed with micronutrient solution containing $\mathrm{Ca}, \mathrm{Cu}, \mathrm{Mg}$ and $\mathrm{Mn}$. Results showed that melon fly infestation was significantly reduced coupled with increased fruit yield and quality. Treated fruits showed significantly higher levels of antioxidants, phenolic acids and flavonoids compared to Control indicating that mineral nutrients protect bitter gourd through activation of antioxidant system in the host combined with their inhibitory effects on oviposition, adult emergence and increased mortality of melon fly larvae. The study established that resistance to melon fly could be induced by supplementing the levels of $\mathrm{Ca}, \mathrm{Cu}$, $\mathrm{Mg}$ and $\mathrm{Mn}$ in bitter gourd fruit by exogenous application at a time when the fruit is most vulnerable to infestation. It appears, therefore, possible to explore foliar micronutrient supplementation as a component of Integrated Pest Management (IPM) strategy for the successful control of melon fly infestation in bitter gourd coupled with higher yield and improved fruit quality.
\end{abstract}

Keywords: Melon fly, Bactrocera cucurbitae, chayote, bitter gourd, host resistance, mineral elements, defence compounds

\section{Introduction}

Melon fly [Bactrocera cucurbitae (Coquillett)] is the most destructive insect pest of cucurbits in India (Narayanan, 1953). The pest severely infests members of the cucurbitaceae family (Dhillon et al., 2005) including the bitter gourd fruit (Momordica charantia L.,) leading to dramatic reduction in yield ranging from 30-90\% (Dhillon et al., 2005). However, chayote (Sechium edule L,) is the lone exception showing resistance to the pest (Shivashankar et al., 2014). Repeated application of insecticides by farmers to control the insect pest is leading to increasing environmental pollution, higher cost of production, residual toxicity and development of resistance in the target insect (Aktar et al., 2009). Hence, integrated pest management (IPM) strategies to control pest damage without the associated adverse effects on the ecosystem (Pretty and Bharucha, 2015) are desirable.

Mineral nutrients play a major role in controlling plant pests and diseases (Christos, 2008). Plants with an optimal nutritional status are known to show the highest resistance/tolerance to pests (Huber et al., 2012). Since mineral micronutrients act as signalling molecules (Hossain et al., 2012) and constitute an integral part of the antioxidant defence machinery of plants (Marschner, 2012), they influence host metabolism to provide protection against pests by way of synthesis of natural defence compounds such as phytoalexins, antioxidants and flavonoids (Schumann et al., 2010). Thus, considering the critical role of micronutrients in development of resistance against insect pests, foliar application of nutrients is being recommended as an IPM strategy to improve plant resistance coupled with long-lasting benefits to the environment (Gupta et al., 2017). The key to using this IPM approach, however, is to maintain optimum nutrient levels in the target tissue, at a time when the crop

Corresponding Author: Seshadri Shivashankar, Division of Plant Physiology and Biochemistry, ICAR-Indian Institute of Horticultural Research, Hesaraghatta Lake P.O., Bengaluru 560089. Karnataka, India. E-mail drsshivashankariihr@yahoo.co.in 
is most vulnerable to insect attack based on crop type, plant life cycle, and cultural practices. Besides, mineral elements also alter the quality of the food source of herbivorous insect pests (GoncalvesAlvim et al., 2004) and thus affect aphid population dynamics under field conditions (Silva et al., 2005).

An exploratory study conducted in our lab on melon fly susceptible bitter gourd and the resistant chayote had revealed considerable differences in the levels of micronutrients in fruits among which $\mathrm{Ca}, \mathrm{Mg}, \mathrm{Mn}$ and $\mathrm{Cu}$ were significantly lower in bitter gourd compared to chayote.Assuming that resistance of chayote to melon fly is governed by the levels of mineral micronutrients, the present study was conducted to determine if application of the four deficient micronutrients on young developing fruits could induce resistance to melon fly infestation in susceptible bitter gourd. Experiments were, therefore, conducted by supplementing young developing bitter gourd fruits with these four critical mineral nutrients and evaluated for the rate of melon fly infestation and fruit yield.

\section{Materials and Methods}

\section{Plant material}

Experiments were conducted at the Indian Institute of Horticultural Research, Bengaluru during 2015 and 2016. Ten-day-old plantlets raised from seeds of bitter gourd were planted at a spacing of $2.5 \mathrm{~m} \times 2.0 \mathrm{~m}$ in pits measuring $0.5 \mathrm{~m}$ length $\times 0.4 \mathrm{~m}$ width $\times 0.5 \mathrm{~m}$ depth during the first week of May. Vines were trained on poles to a height of $1.6 \mathrm{~m}$ above the ground to facilitate spreading on a raised structure made of bamboo canes. Fruits were harvested for studies from third week of July.

\section{Field studies with mineral nutrient spray}

The experimental plants laid out in a Randomized complete block design (RCBD) were supplied with the recommended dose of $\mathrm{N}, \mathrm{P}$ and $\mathrm{K}$ fertilizers plus Farm yard manure and the mixture was incorporated into the top $15 \mathrm{~cm}$ of the ridge at soil preparation. Surface irrigation was given to plants twice a week. Field studies were performed by spraying leaves and young fruits from thirty plants each with mineral nutrient solutions, $T_{1}, T_{2}$ and $T_{3}$ (Table 1) mixed with the surfactant, All Purpose Spray Adjuvant formula (APSA 80, Amway India Enterprises Pvt. Ltd, New Delhi, India) $(0.03 \%)$ (Treated) 10,15 and 20 days after fruit set (DAF) while water mixed with APSA $80(0.03 \%)$ was sprayed on 30 plants (Control) on corresponding days.

Table 1: Composition of treatment formulation used for spray application

\begin{tabular}{lccc}
\hline Mineral nutrients & $\mathbf{T}_{\mathbf{1}}$ & $\mathbf{T}_{\mathbf{2}}$ & $\mathbf{T}_{\mathbf{3}}$ \\
\hline $\mathbf{C a C l}_{2}$ & & $\mathbf{g} / \mathbf{L i t}$ & \\
$\mathbf{M g S O}_{4}$ & 12.15 & 16.2 & 20.250 \\
$\mathbf{Z n S O}_{4}$ & 7.575 & 10.1 & 12.625 \\
MnSO $_{4}$ & 0.173 & 0.231 & 0.289 \\
CuSO$_{4}$ & 0.187 & 0.249 & 0.311 \\
EDTA & 0.191 & 0.255 & 0.319 \\
APSA & 0.075 & 0.10 & 0.125 \\
\hline
\end{tabular}

\section{Rate of melon fly infestation}

Fruits showing brown spot at the site of insect incursion was considered 'infested' while those remaining free of brown spot were considered 'healthy'. Harvested fruits in each batch were observed to record the number of infested fruits.

\section{Measurement of life cycle of melon fly}

Treated and Control fruits were compared for the number of oviposition punctures $/ \mathrm{dm}^{2}$, number of eggs laid, rate of pupation and the number of adults emerged.

\section{Biochemical studies}

\section{Antioxidative enzymes}

Catalase (CAT, E.C. 1.11.1.6) activity One g of fruit tissue was homogenized in $8.0 \mathrm{ml}$ of $67 \mathrm{mM}$ sodium phosphate buffer, $\mathrm{pH} 7.0$ and centrifuged at $12,000 \times \mathrm{g}$ for $10 \mathrm{~min}$ at $4^{\circ} \mathrm{C}$ The supernatant was 
used as the crude enzyme source. The assay mixture $(3 \mathrm{ml})$ contained $100 \mathrm{mM}$ Tris- $\mathrm{HCl}$ buffer, $\mathrm{pH}$ 7.0, $0.1 \mathrm{ml}$ crude enzyme extract, and $200 \mathrm{mM} \mathrm{H}_{2} \mathrm{O}_{2}$. Specific activity of CAT was determined using the molar extinction coefficient of $\mathrm{H}_{2} \mathrm{O}_{2}$ at $240 \mathrm{~nm}\left(\epsilon=43.6 \mathrm{M}^{-1} \mathrm{~cm}^{-1}\right)$ and expressed as nmoles $\mathrm{mg}$ protein ${ }^{-1} \min ^{-1}$ (Luck, 1965).

Peroxidase (POD) activity POD (EC 1.11.1.7) enzyme was extracted by grinding $1 \mathrm{~g}$ fresh tissue in a chilled mortar and pestle in $100 \mathrm{mM}$ sodium phosphate buffer $(\mathrm{pH} 7.0)$. The homogenate was filtered through four layers of muslin cloth and centrifuged at $18,000 \times \mathrm{g}$ for $15 \mathrm{~min}$ at $4^{\circ} \mathrm{C}$ and the supernatant was used as enzyme source. The reaction mixture $(5 \mathrm{ml})$ for the assay of POD contained $50 \mathrm{mM}$ sodium phosphate buffer ( $\mathrm{pH} 7.0), 20 \mathrm{mM}$ guaiacol and $100 \mu \mathrm{l}$ enzyme extract. The reaction was initiated by the addition of $0.042 \%(\mathrm{v} / \mathrm{v}) \mathrm{H}_{2} \mathrm{O}_{2}$, and the increase in absorbance at $470 \mathrm{~nm}$ was monitored for $3 \mathrm{~min}$ at $30 \mathrm{~s}$ intervals with a T80+ UV-Visible spectrophotometer (PG Instruments Inc., UK) and estimated according to Saroop et al. (2002). The specific activity of POD (nmoles mg ${ }^{-1}$ protein $\left.\mathrm{min}^{-1}\right)$ was calculated using the molar extinction coefficient for guaiacol $\left(26.6 \mathrm{M}^{-1} \mathrm{~cm}^{-1}\right)$.

Superoxide dismutase (SOD) activity SOD (E.C.1.15.1.1) enzyme was extracted by homogenizing $1 \mathrm{~g}$ fresh fruit tissue in $50 \mathrm{mM}$ sodium phosphate buffer, $\mathrm{pH} 7.8$. The homogenate was centrifuged at $10,000 \times g$ for $10 \mathrm{~min}$ at $4^{\circ} \mathrm{C}$ and the clear supernatant containing the enzyme was used to assay for SOD activity based on its ability to inhibit the photochemical reduction of nitro-blue tetrazolium (NBT) following Beauchamp and Fridovich (1971). The reaction mixture $(3 \mathrm{ml})$ contained $50 \mathrm{mM}$ sodium phosphate buffer, $\mathrm{pH}$ 7.8, $100 \mathrm{mM}$ EDTA, $130 \mathrm{mM}$ methionine, $0.75 \mathrm{mM}$ NBT, $20 \mu \mathrm{M}$ riboflavin, and $0.1 \mathrm{ml}$ crude enzyme extract. Reaction was initiated by illuminating the tubes under four $40 \mathrm{~W}$ fluorescent lamps for $8 \mathrm{~min}$ following which absorbance at $560 \mathrm{~nm}$ was recorded against a blank mixture maintained in dark. One Unit of SOD activity was defined as the amount of enzyme required to inhibit the photo-reduction of NBT by $50 \%$ compared to that caused by the superoxide generated in the blank by the reaction between photo-reduced riboflavin and oxygen under the assay conditions. SOD enzyme activity was expressed as Units $\mathrm{mg}^{-1}$ protein.

\section{Antioxidant capacity}

\section{Ferric reducing anti-oxidant power (FRAP)}

FRAP was assayed according to Benzie and Strain (1996) based on the increase in absorbance at $593 \mathrm{~nm}$ The anti-oxidant capacity of a sample which is related to its ability to reduce ferric ions, was expressed as ascorbic acid equivalent anti-oxidant capacity (AEAC; in mg ascorbic acid $100 \mathrm{~g}^{-1} \mathrm{FW}$ of tissue), where the reducing power of a $1.0 \mathrm{mg}$ sample was equivalent to the reducing power of 1 nmole ascorbic acid.

\section{2, 2-diphenyl-l-picrylhydrazyl (DPPH) radical scavenging activity (DPPH)}

DPPH radical scavenging activity was estimated following Brand-Williams et al. (1995) with some modifications. A $0.2 \mathrm{ml}$ sample of $80 \%(\mathrm{v} / \mathrm{v})$ methanolic extract of fruit tissue was mixed with $0.3 \mathrm{ml}$ of $10 \mathrm{mM}$ acetate buffer, $\mathrm{pH} 5.4$ and $2.5 \mathrm{ml} 0.008 \%(\mathrm{w} / \mathrm{v}) \mathrm{DPPH}$ in $100 \%(\mathrm{v} / \mathrm{v})$ methanol. The mixture was incubated at room temperature $\left(30^{\circ} \mathrm{C}\right)$ for $30 \mathrm{~min}$, followed by measurement of absorbance at $517 \mathrm{~nm}$. DPPH scavenging activity was expressed as $\mathrm{mg}$ ascorbic acid equivalents $\mathrm{g}^{-1}$ FW of sample tissue.

\section{Total phenols and flavonoids}

Phenolic acids and flavonoids were extracted in $80 \%(\mathrm{v} / \mathrm{v})$ methanol. Phenolic acids were estimated following Singleton and Rossi (1965) using gallic acid as standard and expressed as mg gallic acid equivalents $\mathrm{g}^{-1}$ fresh weight (FW) of sample tissue. Total flavonoids were determined according to Kim et al. (2003) using catechin as standard and expressed as $\mathrm{mg}$ catechin equivalents $\mathrm{g}^{-}$ ${ }^{1} \mathrm{FW}$ of sample tissue.

\section{LC-MS separation of phenolic acids and flavonoids}

Phenolic acid standards namely ferulic acid, 2,4 dihydroxy benzoic acid, caffeic acid, gallic acid, gentisic acid, $o$-coumaric acid, $p$-coumaric acid, $p$-hydroxy benzoic acid, protocatechuic acid, salicylic acid, syringic acid, $t$-cinnamic acid, vanillic acid, chlorogenic acid and flavanoid standards namely catechin, hesperitin, apigenin, neringenin, myrcetin, rutin, luteoline, quercetin, umbelliferone 
were prepared in $80 \%$ ethanol. The organic solvents used as mobile phase for liquid chromatography were of chromatographic/MS grade and all other reagents were of analytical grade. Water purified in Milli-Q (Millipore) system was used to prepare the mobile phases. All solvents used for mobile phase were filtered through membranes with a pore size of $0.45 \mu \mathrm{m}$. Standard curves for individual phenolic acids and flavonoids were prepared using different concentration of individual compounds.

An Acquity UPLC-H class coupled with TQD-MS/MS (Waters, USA) and equipped with ESI source, degasser, quaternary pump, automatic injection system $(0-10 \mu 1)$, diode array detector and a temperature control compartment for the analytical column was used for determinations of phenolic acids and flavonoids. The system, controlled by Mass lynx software, allowed for simultaneous detection at multiple wavelengths, MRM for individual masses Table (2) and administration of data collection and treatment system. All the phenolic acids and flavonoids were identified and quantified by the molecular weight (parent mass $\mathrm{m} / \mathrm{z}$ ) of most abundant fragmented daughters.

Table 2: MRM data for phenolic acids

\begin{tabular}{lcccccc}
\hline Compound & $\begin{array}{c}\text { Formula/ } \\
\text { Mass }\end{array}$ & $\begin{array}{c}\text { Parent } \\
\mathbf{m} / \mathbf{z}\end{array}$ & $\begin{array}{c}\text { Cone } \\
\text { Voltage }\end{array}$ & Daughters & $\begin{array}{c}\text { Collision } \\
\text { Energy }\end{array}$ & $\begin{array}{c}\text { Ion } \\
\text { Mode }\end{array}$ \\
\hline Caffeic acid & 180 & 178.90 & 30 & 135.05 & 16 & ES- \\
2,4-Dihydroxybenzoic acid & 154 & 152.90 & 28 & 65.02 & 18 & $\begin{array}{c}\text { ES- } \\
\text { Chlorogenic acid }\end{array}$ \\
Ferulic acid & 354 & 352.97 & 22 & 191.10 & 18 & ES- \\
Gallic acid & 194 & 192.90 & 26 & 134.02 & 14 & ES- \\
Gentisic acid & 170 & 168.90 & 28 & 125.03 & 12 & ES- \\
$\boldsymbol{o}$-Coumaric acid & 154 & 152.90 & 24 & 108.98 & 12 & ES- \\
p-Coumaric acid & 164 & 162.90 & 22 & 119.06 & 12 & ES- \\
$\boldsymbol{p}$-Hydroxybenzoic acid & 164 & 162.90 & 24 & 119.05 & 14 & ES- \\
Protocatechuic acid & 138 & 136.90 & 26 & 93.01 & 12 & ES- \\
Salicylic acid & 154 & 152.90 & 26 & 109.05 & 16 & ES- \\
Syringic acid & 138 & 136.90 & 28 & 93.10 & 14 & ES- \\
$\boldsymbol{t}$-Cinnamic acid & 198 & 196.97 & 26 & 182.07 & 10 & ES- \\
Vanillic acid & 148 & 146.90 & 26 & 103.05 & 10 & ES- \\
\hline
\end{tabular}

\section{LC and MS-MS conditions}

Mobile phase consisted of (A) an aqueous component containing $0.1 \%$ formic acid in water and (B) organic phase containing $0.2 \%$ formic acid in methanol. The solvent gradient had $90 \%$ (A) and $10 \%$ (B) initially which was changed to $70 \%$ (A) and $30 \%$ (B) at $4.0 \mathrm{~min}$. At $5.0 \mathrm{~min}$, the gradient was changed to $60 \%$ (A) and $40 \%$ (B) followed by $80 \%$ (A) and $20 \%$ (B) at $10.0 \mathrm{~min}$. The final gradient at $12.0 \mathrm{~min}$ was $90 \%$ (A) and $10 \%$ (B) for $2.0 \mathrm{~min}$. At $14 \mathrm{~min}$, the system was returned to initial conditions and held for $1 \mathrm{~min}$ for equilibration before the next injection. The flow rate was maintained at $0.3 \mathrm{ml} / \mathrm{min}$. The analytical column, $2.1 \times 50 \mathrm{~mm}$ UPLC BEH- C18 column (Waters, USA) with $1.7 \mu \mathrm{m}$ particle size maintained at $25^{\circ} \mathrm{C}$, was protected by a Vanguard BEH C-18, $1.7 \mu \mathrm{m}$ particle size guard column (Waters, USA). The sample injection volume was $2 \mu \mathrm{l}$ for both phenolic acids and flavonoids. The eluted metabolites were monitored using the UPLC column. Effluent was pumped directly without split into the TQD-MS/MS (Waters, USA) system, optimized for analysis of phenolic acids and flavonoids.

\section{Lignin content}

Lignin content was estimated according to Doster and Bostock (1988) with modifications. Samples were extracted in methanol for $48 \mathrm{~h}$ after which residue was dried in a desiccator and ground to a fine powder. Five hundred milligrams of dry powder were mixed with $5 \mathrm{ml}$ of $2 \mathrm{M} \mathrm{HCl}$ and $0.5 \mathrm{ml}$ of thioglycolic acid. Samples were heated at $95^{\circ} \mathrm{C}$ for $4 \mathrm{~h}$ and centrifuged at $3,000 \times g$ for $20 \mathrm{~min}$. Pellets were washed twice with deionised water, extracted with $2 \mathrm{~mL}$ of $0.5 \mathrm{M} \mathrm{NaOH}$ for $18 \mathrm{~h}$ followed by 2 $\mathrm{ml}$ of deionised water at room temperature. Sample was centrifuged at $15,000 \times g$, supernatants collected, mixed, acidified with $1 \mathrm{ml}$ of concentrated $\mathrm{HCl}$ and stored at $5^{\circ} \mathrm{C}$ overnight. Sample was centrifuged, residue dissolved in $10 \mathrm{ml}$ of $0.5 \mathrm{M} \mathrm{NaOH}$ and centrifuged at $15.000 \times \mathrm{g}$. The absorbance 
of the clear supernatant was measured at $280 \mathrm{~nm}$ and the lignin content was expressed as $\mathrm{A}_{280} . \mathrm{g}^{-1}$ dry weight of sample.

\section{Extraction of Lignin monomers}

Lignin monomers were extracted from protein-free cell wall fraction following Lima et al. (2013). Fruit tissue $(5 \mathrm{~g})$ was homogenized with $50 \mathrm{mM}$ potassium phosphate buffer $(\mathrm{pH} 7.0)$ and centrifuged at $10.000 \mathrm{~g}$ for $4 \mathrm{~min}$. The pellet was washed sequentially with phosphate buffer ( $\mathrm{pH} 7.0)$ followed by $1 \%(\mathrm{v} / \mathrm{v})$ Triton $\mathrm{X}-100$ in $\mathrm{pH} 7.0$ buffer, $1 \mathrm{M} \mathrm{NaCl}$ in $\mathrm{pH} 7.0$ buffer, distilled water and finally acetone. The pellet was dried in an oven at $60^{\circ} \mathrm{C}$ for $24 \mathrm{~h}$ and cooled in a vacuum desiccator. The dry mass containing protein-free cell wall fraction $(100 \mathrm{mg})$ was transferred to a Pyrex glass ampoule containing $1 \mathrm{ml}$ of $2 \mathrm{M} \mathrm{NaOH}$ and $1 \mathrm{ml}$ of nitrobenzene and sealed. The ampoules were heated at $170^{\circ} \mathrm{C}$ for $90 \mathrm{~min}$ on a silicone oil bath with occasional stirring. The tubes were cooled to room temperature, washed twice with chloroform, acidified to $\mathrm{pH} 2.0$ with $2 \mathrm{M} \mathrm{HCl}$ and extracted twice with chloroform. The organic extracts were combined, dried and re-suspended in $1 \mathrm{ml}$ of a mixture of methanol and $4.5 \%$ acetic acid in water $(20: 80, \mathrm{v} / \mathrm{v})$. The samples were filtered through a $0.2 \mu \mathrm{m}$ nylon filter before analysis by high-performance liquid chromatography.

\section{HPLC separation and determination of lignin monomers}

HPLC analyses were carried out on a Shimadzu LC-10A system (Shimadzu, Kyoto, Japan) consisting of a liquid chromatograph equipped with UV-VIS detector (10A), binary pump and controlled by Shimadzu class $V P$ workstation software. The column used was Synergi, $250 \times 4.6 \mathrm{~mm}$, $4 \mu \mathrm{m}$ Hydro-RP, C 18 (Phenomenex, Torrance, CA, USA) with guard column having C18 cartridge (cat no. 7511, Phenomenex). Samples were injected using a $20 \mu \mathrm{L}$ loop (Rheodyne, Rohnert Park, CA, USA), and the absorption of separated compounds was monitored at $280 \mathrm{~nm}$. The temperatures of both the sample column and guard column were thermostatically controlled at $35^{\circ} \mathrm{C}$. The flow rate of the mobile phase consisting of $4.5 \%$ acetic acid (solvent A) and methanol (solvent B) was maintained at $1 \mathrm{ml} \mathrm{min}{ }^{-1}$. The instrument was run in gradient mode for which conditions were maintained as follows, $0-20 \mathrm{~min}, 10 \% \mathrm{~B} ; 20-25 \mathrm{~min}, 10-15 \% \mathrm{~B} ; 25-40 \mathrm{~min}, 15-20 \% \mathrm{~B} ; 40-60 \mathrm{~min}$, $20-45 \% \mathrm{~B} ; 60-65 \mathrm{~min}, 45-75 \% \mathrm{~B}, 65-75 \mathrm{~min}, 75-100 \% \mathrm{~B}$. The concentration of phenolic acid was expressed as $\mu \mathrm{g} 100 \mathrm{~g}^{-1} \mathrm{FW}$ of sample. Estimation of lignin monomers in protein-free cell wall fractions was carried out by HPLC on a Shimadzu Series LC-10A system consisting of a liquid chromatograph connected to a UV-VIS detector, binary pump and controlled by Shimadzu Class VP Workstation software. The column used was Luna HST $\mathrm{C}_{18}(2)(100 \times 0.3 \mathrm{~mm}, 2.5 \mu \mathrm{m}$, Phenomenex $)$ with security guard column having C 18 cartridge (cat no: 4287, Phenomenex). The temperatures of both the columns were thermostatically controlled at $30^{\circ} \mathrm{C}$. Samples were injected using a $20 \mu$ loop (Rheodyne). Methanol (B) and 4.5\% acetic acid in water (A) in 20:80 ratio were used as the mobile phase at a flow rate of $0.3 \mathrm{ml} \mathrm{min}{ }^{-1}$. The instrument was run in isocratic mode and the peak absorption was monitored at $290 \mathrm{~nm}$. Aldehyde standards, $p$-hydroxybenzaldehyde, vanillin and syringaldehyde (Sigma-Aldrich Corp., St Louis, MO, USA) dissolved in methanol and filtered through $0.2 \mu$ m nylon filter were also analysed simultaneously for which the retention times were 7.76, 9.72 and $11.02 \mathrm{~min}$, respectively.

\section{Protein content}

Protein content was determined using Folin-phenol reagent (Lowry et al., 1951). One gram of tissue was homogenized in $5 \mathrm{ml}$ of $0.1 \mathrm{M}$ Na-phosphate buffer $(\mathrm{pH} 7.6)$ and centrifuged at 2,500 $\times \mathrm{g}$ for $10 \mathrm{~min}$ at room temperature. One hundred microliters of supernatant were mixed with $900 \mu \mathrm{l}$ water and mixed with $5 \mathrm{ml}$ alkaline copper reagent $[50 \mathrm{ml}$ Reagent A plus $1 \mathrm{ml}$ Reagent B; where Reagent $\mathrm{A}=2 \%(\mathrm{w} / \mathrm{v})$ sodium carbonate in $0.1 \mathrm{M} \mathrm{NaOH}$ and Reagent $\mathrm{B}=0.5 \%(\mathrm{w} / \mathrm{w})$ copper sulphate in $1 \%$ $(\mathrm{w} / \mathrm{w})$ potassium sodium tartrate]. The reaction mixture was allowed to stand at room temperature for $10 \mathrm{~min}$. Then, $0.5 \mathrm{ml}$ of Folin-phenol reagent was added, mixed and incubated for $30 \mathrm{~min}$ in the dark. The amount of protein was calculated from the absorbance at $660 \mathrm{~nm}$ and expressed as $\mathrm{mg} \mathrm{g}^{-1} \mathrm{FW}$.

\section{Mineral nutrients}

Tissue was dried to constant weight at $70^{\circ} \mathrm{C}$ in an hot air oven and ground to a fine powder. Nitrogen was determined by titrimetry after Kjeldahl digestion (Jackson, 1973). For all the other 
nutrient elements, $1 \mathrm{~g}$ of dry tissue was digested with nitric acid-perchloric acid (9:4) mixture. Phosphorous, potassium and the micro-nutrient elements, $\mathrm{Fe}, \mathrm{Mn}, \mathrm{Cu}$, and $\mathrm{Zn}$ were estimated according to Jackson (1973). Ca and Mg were estimated following Jones et al. (1991). Perkin ElmerA-Analyst-200 model atomic absorption spectrophotometer (Perkin Elmer, Waltham, MA, USA) was used to estimate the microelements.

\section{Histochemical staining}

Lignin histochemistry was studied using Wiesner reagent (Pomar et al., 2004). Hand-cut crosssections of Control and Treated bitter gourd fruits were incubated in phloroglucinol solution $(2 \%$ in $95 \%$ ethanol) or $95 \%$ ethanol (staining control) for $10 \mathrm{~min}$ followed by treatment with $18 \% \mathrm{HCl}$ for 5 min, and directly observed under bright-field using a DM2500 Fluorescence microscope (Leica Instruments, Wetzlar, Germany).

\section{Statistical analysis}

Field experiments: Experiments were laid out in a Randomized Complete Block Design (RCBD) with five replications. Each replication consisted of six plants of bitter gourd. Data on the rate of infestation, number of oviposition punctures, number of eggs laid, rate of pupation and the number of adults emerged during 2015 and 2016 were pooled and subjected to analysis of variance (ANOVA) using the MSTAT statistical program (Michigan State University, East Lansing, MI, USA) and were presented as means \pm standard errors (SE).

Laboratory experiments: Differences between Control and Treatment were tested by applying Student's $t$-test with three replications and were presented as means \pm standard errors (SE) (Panse and Sukhatme, 1978).

\section{Results}

\section{Levels of mineral elements in bitter gourd and chayote fruits}

The levels of mineral elements in bitter gourd and chayote fruits showed statistically significant differences for the levels of microelements among which $\mathrm{Ca}, \mathrm{Mg}, \mathrm{Mn}$ and $\mathrm{Cu}$ were found to be significantly lower in bitter gourd Table (3).

Table 3: Concentration of micronutrient elements in healthy chayote (CC) and bitter gourd (BG) fruits

\begin{tabular}{|c|c|c|}
\hline \multirow{2}{*}{ Minerals } & \multicolumn{2}{|c|}{ Healthy } \\
\hline & $\mathbf{C C}$ & BG \\
\hline $\mathrm{Ca} \%$ & $1.62 \pm 0.13 \mathrm{a}$ & $0.45 \pm 0.02 b$ \\
\hline Fe ppm & $61.2 \pm 2.56 b$ & $92.2 \pm 5.32 \mathrm{a}$ \\
\hline Zn ppm & $23.1 \pm 1.03 \mathrm{~b}$ & $26.2 \pm 1.43 a$ \\
\hline Mn ppm & $24.9 \pm 0.88 \mathrm{a}$ & $16.6 \pm 1.09 b$ \\
\hline
\end{tabular}

Means with different letters represent statistically significant differences between CC and BG according to Student's t test $(\mathrm{P} \leq .05)$.

\section{Field studies with mineral supplements}

The rate of melon fly infestation in control was very high at $76.49 \%$ in which the fruit pulp showed rotting symptoms and turned brown (Fig.1) and fruit yield was the lowest at $131.35 \mathrm{~kg}$ from a total of six harvests while plants treated with $T_{1}, T_{2}$ and $T_{3}$ showed significantly lower rate of infestation and higher cumulative fruit yield compared to Control Table (4). Among the three treatments, $\mathrm{T}_{2}$ gave the lowest rate of melon fly infestation combined with a significantly higher fruit yield than $T_{1}$ or $T_{3}$ Table (4). Based on the results, further experiments on the mode of action of foliar application of mineral nutrients on melon fly infestation was limited to $T_{2}$ treatment only. 


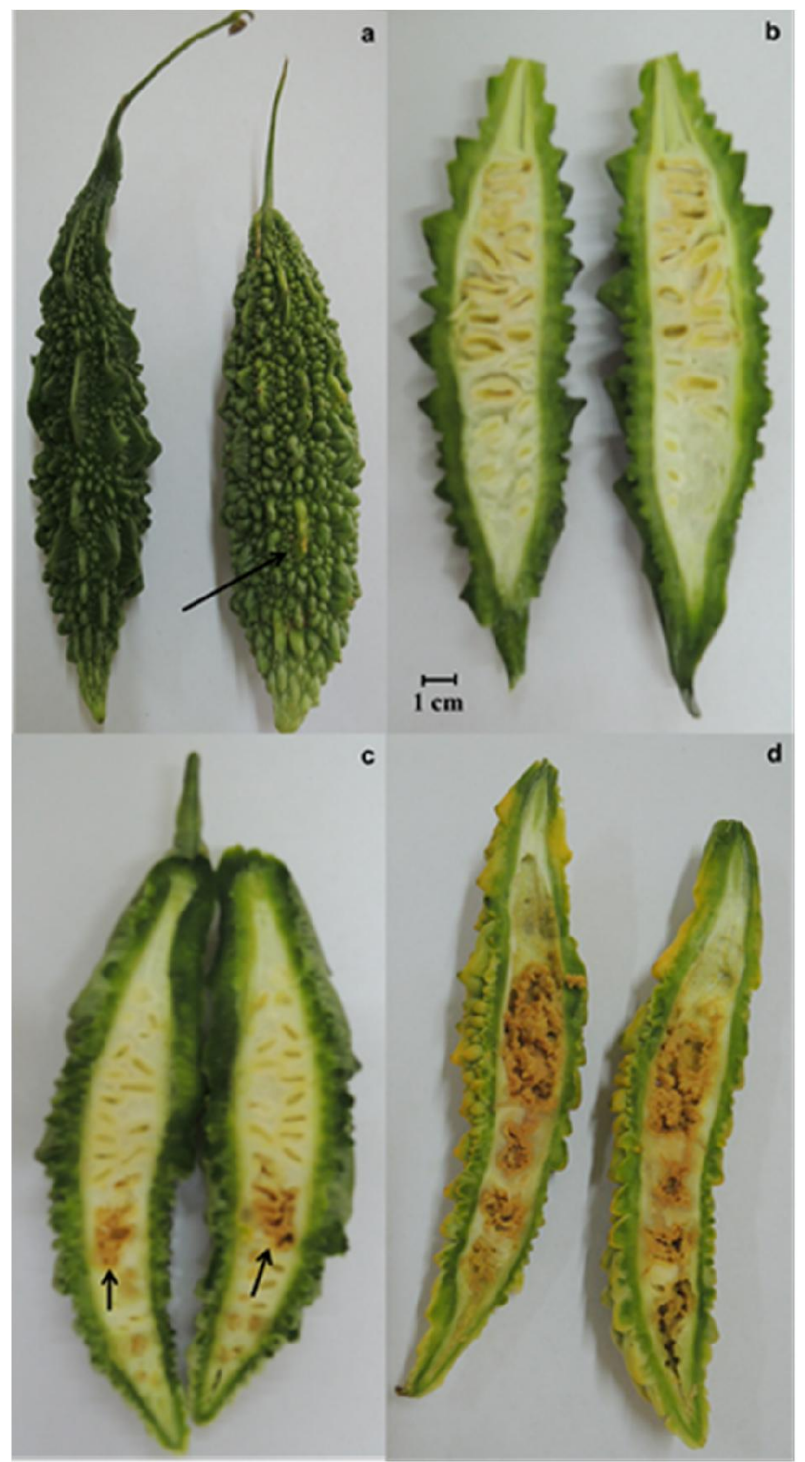

Fig. 1: Healthy (Panels a and b) and melon fly- infested (Panels $c$ and d) bitter gourd fruits. Arrow indicates the site of infestation by melon fly. Scale bar $=1.0 \mathrm{~cm}$

Table 4: Melon fly infestation and fruit yield in control and treated fruits of bittergourd

\begin{tabular}{cccccc}
\hline Treatment & $\begin{array}{c}\text { No of } \\
\text { harvests }\end{array}$ & $\begin{array}{c}\text { No.of } \\
\text { harvested } \\
\text { fruits }\end{array}$ & $\begin{array}{c}\text { Fruit yield } \\
\text { (kg) }\end{array}$ & $\begin{array}{c}\text { No.of infested } \\
\text { fruits }\end{array}$ & \% infested fruits \\
\hline Control & 6 & $604 \pm 15.02$ & $131.35 \pm 5.30$ & $462 \pm 6.79$ & $76.49 \pm 4.23 \mathrm{a}$ \\
$\mathbf{T}_{\mathbf{1}}$ & 6 & $648 \pm 7.89$ & $146.24 \pm 6.74$ & $84 \pm 3.86$ & $12.96 \pm 1.54 \mathrm{~b}$ \\
$\mathbf{T}_{\mathbf{2}}$ & 6 & $819 \pm 17.00$ & $238.40 \pm 14.15$ & $39 \pm 1.76$ & $4.77 \pm 0.51 \mathrm{~d}$ \\
$\mathbf{T}_{\mathbf{3}}$ & 6 & $684 \pm 9.92$ & $160.58 \pm 8.05$ & $42 \pm 2.08$ & $6.14 \pm 0.83 \mathrm{c}$ \\
\hline
\end{tabular}

Means with different letters represent statistically significant differences between Control and Treatments according to Student's $t$ test $(\mathrm{P} \leq .05)$.

The field study using mineral supplementation showed that $\mathrm{T}_{2}$ treated fruits of bitter gourd had attained nearly the same levels of $\mathrm{Ca}$ and $\mathrm{Cu}$ as in Chayote while the levels of $\mathrm{Mg}$ and $\mathrm{Mn}$ were about $50 \%$ of their levels compared to Chayote Table (5). Data on the number of oviposition punctures, number of eggs laid, rate of pupation and the rate of adult emergence were significantly lower in $T_{2}$ treated plants compared to Control. It was clear that oviposition was strongly inhibited in $T_{2}$ treated 
fruits compared to Control and the slower rates of pupation and adult emergence led to increased mortality Table (6).

Table 5: Concentration of mineral elements in control and treated fruits of bittergourd

\begin{tabular}{ccc}
\hline Minerals & Control & Treated $\left.\mathbf{( T}_{\mathbf{2}}\right)$ \\
\hline $\mathbf{N} \%$ & $2.0 \pm 0.095 \mathrm{~b}$ & $2.31 \pm 0.054 \mathrm{a}$ \\
$\mathbf{P \%}$ & $0.48 \pm 0.032 \mathrm{~b}$ & $1.70 \pm 0.158 \mathrm{a}$ \\
$\mathbf{K} \%$ & $3.8 \pm 0.131 \mathrm{~b}$ & $6.45 \pm 0.226 \mathrm{a}$ \\
$\mathbf{C a} \%$ & $0.76 \pm 0.061 \mathrm{~b}$ & $1.37 \pm 0.073 \mathrm{a}$ \\
$\mathbf{M g} \%$ & $0.39 \pm 0.042 \mathrm{a}$ & $0.48 \pm 0.036 \mathrm{a}$ \\
$\mathbf{F e ~ p p m}$ & $73 \pm 1.190 \mathrm{~b}$ & $119 \pm 2.455 \mathrm{a}$ \\
$\mathbf{M n ~ p p m}$ & $15 \pm 0.208 \mathrm{~b}$ & $31 \pm 0.708 \mathrm{a}$ \\
$\mathbf{C u}$ ppm & $10 \pm 0.147 \mathrm{~b}$ & $12 \pm 0.326 \mathrm{a}$ \\
$\mathbf{Z n ~ p p m}$ & $24 \pm 1.372 \mathrm{~b}$ & $33 \pm 1.871 \mathrm{a}$ \\
\hline
\end{tabular}

Means with different letters represent statistically significant differences between Control and Treated according to Student's t test $(\mathrm{P} \leq .05)$.

Table 6: Life cycle of melon fly in control and treated $\left(\mathrm{T}_{2}\right)$ fruits of bitter gourd

\begin{tabular}{llcccc}
\hline Treatment & $\begin{array}{c}\text { No. of oviposition } \\
\text { punctures/dm }\end{array}$ & $\begin{array}{c}\text { No. of eggs / } \\
\text { puncture }\end{array}$ & $\begin{array}{c}\text { No. of days for } \\
\text { pupation }\end{array}$ & $\begin{array}{c}\text { No. of days } \\
\text { for adult } \\
\text { emergence }\end{array}$ & $\begin{array}{c}\text { No. of adults } \\
\text { emerged } \\
\mathbf{( \% )}\end{array}$ \\
\hline Control & $12.0 \pm 1.73 \mathrm{a}$ & $8.0 \pm 0.33 \mathrm{a}$ & $5.92 \pm 0.35 \mathrm{~b}$ & $6.69 \pm 0.23 \mathrm{~b}$ & $85.6 \pm 2.72 \mathrm{a}$ \\
Treated $\left(\mathbf{T}_{\mathbf{2}}\right)$ & $3.0 \pm 0.32 \mathrm{~b}$ & $2.0 \pm 0.12 \mathrm{~b}$ & $7.88 \pm 0.09 \mathrm{a}$ & $9.23 \pm 0.12 \mathrm{a}$ & $11.4 \pm 0.23 \mathrm{~b}$ \\
\hline
\end{tabular}

Means with different letters represent statistically significant differences between Control and Treated according to Student's $t$ test $(\mathrm{P} \leq .05)$.

Changes in antioxidant enzymes, antioxidant capacity, phenolic acids and flavonoids in $T_{2}$ Treated fruits

The study showed that the levels of total phenols, flavonoids, DPPH, FRAP, activities of POD and SOD were significantly higher in $T_{2}$ treated fruits compared to Control while CAT activity was lower in $T_{2}$ treated fruits (Fig. 2). $T_{2}$ treated fruits showed higher concentrations of flavonoids compared to control fruits Table (7). The data profiles of phenolic acids separated and identified based on MRM analysis showed significantly higher values in $T_{2}$ treated fruits compared to control Table (8) with the exception of vanillic acid, 2,4-dihydroxy benzoic acid, gentisic acid and protocatechuic acid.

Table 7: Levels of flavonoids in control and treated fruits of bittergourd

\begin{tabular}{|c|c|c|}
\hline $\begin{array}{l}\text { Flavonoids } \\
{\mathrm{mg} 100 \mathrm{~g}^{-1} \mathrm{FW}}\end{array}$ & Control & Treated $\left(T_{2}\right)$ \\
\hline Umbelliferone & $8.72 \pm 0.25 \mathrm{~b}$ & $21.80 \pm 1.11 \mathrm{a}$ \\
\hline Apigenin & $19.37 \pm 0.61 \mathrm{~b}$ & $58.11 \pm 1.28 \mathrm{a}$ \\
\hline Neringenin & $18.84 \pm 0.42 \mathrm{~b}$ & $32.97 \pm 1.19 \mathrm{a}$ \\
\hline Luteoline & $150.80 \pm 2.53 \mathrm{~b}$ & $339.30 \pm 1.62 \mathrm{a}$ \\
\hline Catechin & $473.94 \pm 1.43 \mathrm{~b}$ & $1026.87 \pm 3.61 \mathrm{a}$ \\
\hline Hesperitin & $79.04 \pm 1.72 b$ & $118.56 \pm 2.56 \mathrm{a}$ \\
\hline Quercetin & $78.40 \pm 1.27 \mathrm{~b}$ & $470.40 \pm 3.68 \mathrm{a}$ \\
\hline Myrcetin & $24.12 \pm 0.68 \mathrm{~b}$ & $48.24 \pm 1.21 \mathrm{a}$ \\
\hline Rutin & $17.52 \pm 0.77 b$ & $43.80 \pm 1.38 \mathrm{a}$ \\
\hline Kaempferol & $11.24 \pm 0.48 b$ & $28.32 \pm 1.14 \mathrm{a}$ \\
\hline Epicatechin & $10.25 \pm 0.25 b$ & $16.47 \pm 0.56 \mathrm{a}$ \\
\hline Epigallo catechin & $19.28 \pm 0.53 b$ & $31.22 \pm 1.20 \mathrm{a}$ \\
\hline
\end{tabular}


Table 8: Levels of phenolic acids in Control and Treated fruits of bittergourd

Phenolic acids

mg $100 g^{-1}$ FW

Chlorogenic acid

Vanillic acid

Syringic acid

Ferulic acid

Caffeic acid

Gallic acid

p-coumaric acid

o-coumaric acid

2,4-dihydroxy benzoic acid

Gentisic acid

Protocatechuic acid

$t$-cinnamic acid

p-OH benzoic acid

Salicylic acid

Salicylic acid $\quad 35.39 \pm 0.622 \mathrm{~b} \quad 67.54 \pm 1.213 \mathrm{a}$ Student's t test $(\mathrm{P} \leq .05)$.

Treated $\left(\mathbf{T}_{2}\right)$

$0.98 \pm 0.018 \mathrm{a}$

$2.76 \pm 0.116 \mathrm{a}$

$0.73 \pm 0.020 \mathrm{a}$

$6.03 \pm 0.220 \mathrm{a}$

$0.08 \pm 0.009 \mathrm{a}$

$0.06 \pm 0.007 \mathrm{a}$

$0.69 \pm 0.022 \mathrm{a}$

$0.49 \pm 0.021 \mathrm{a}$

$0.01 \pm 0.002 \mathrm{~b}$

$0.004 \pm 0.001 \mathrm{~b}$

$0.17 \pm 0.004 \mathrm{~b}$

$0.09 \pm 0.007 \mathrm{a}$

$19.58 \pm 0.547 \mathrm{a}$

$67.54 \pm 1.213 \mathrm{a}$

$0.26+0.015$

$0.025 \pm 0.0002 b$

$17.99 \pm 0.219 \mathrm{a}$
( T)

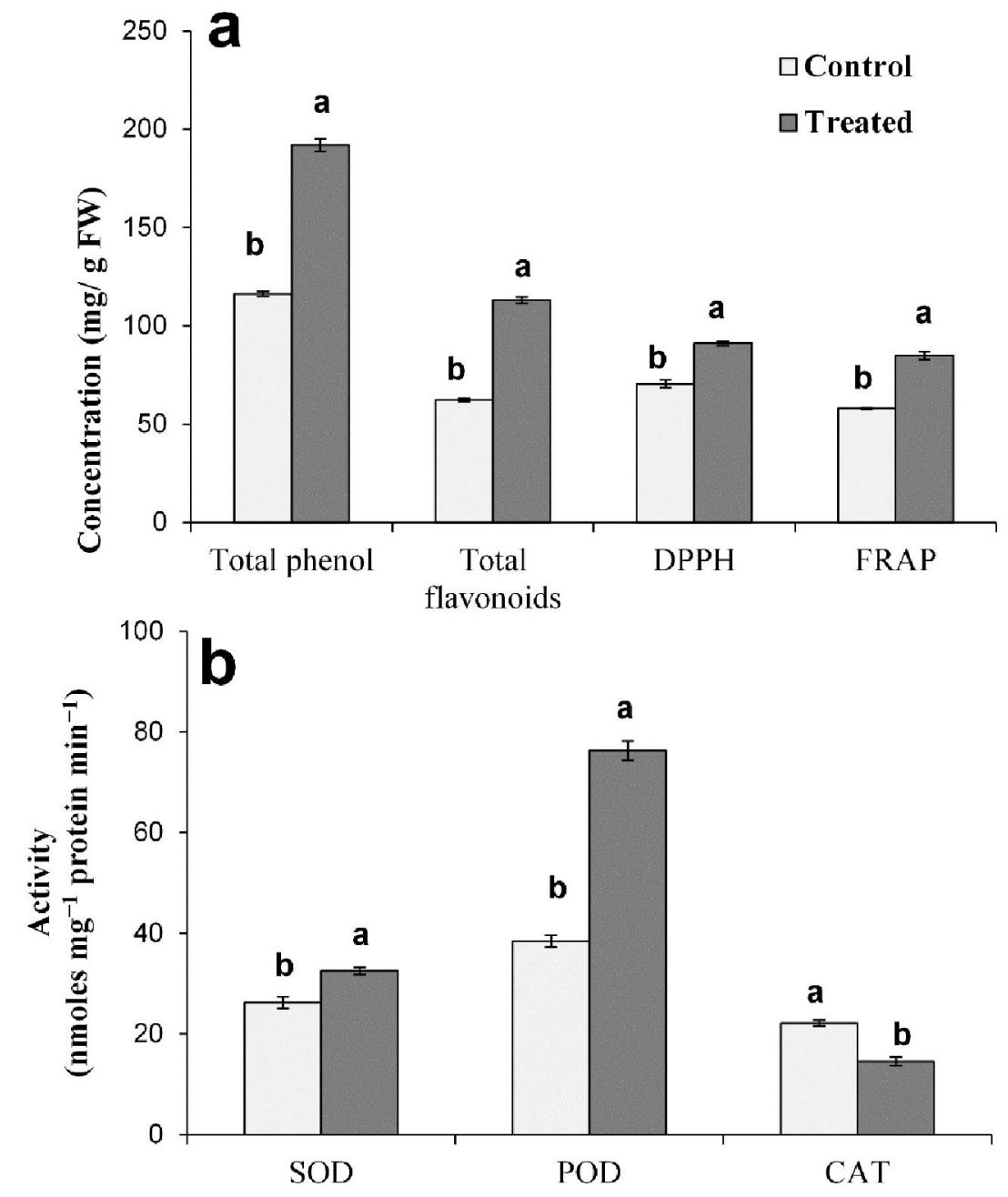

Fig. 2: Levels of antioxidants and scavenging enzymes in Control and Treated fruits of bittergourd. Means with different letters represent statistically significant differences between Control and Treated according to Student's t test $(\mathrm{P} \leq .05)$. 


\section{Histochemical staining}

Histochemical staining of fruit cross-sections following infestation showed formation of highly cross linked guaiacyl $(\mathrm{G})$ units (Brown) at the site of infestation in $\mathrm{T}_{2}$ treated fruit while Control fruit showed formation of syringyl (S) units (Red) (Fig. 3). Lignin content and the levels of monomers of $p$-hydroxycinnamyl $(\mathrm{H}), \mathrm{S}$ and $\mathrm{G}$ moieties were significantly higher in $\mathrm{T}_{2}$ treated fruits compared to Control fruits (Fig. 4).

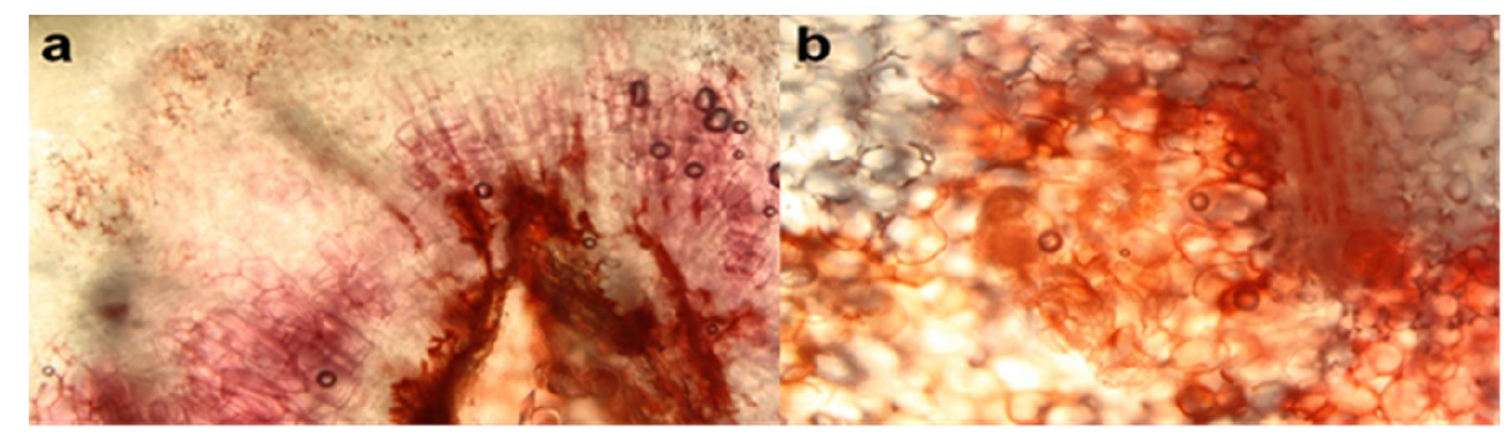

Fig. 3: Histochemical staining of lignin in cross-sections of bitter gourd fruit following melon fly infestation. Hand-cut cross sections of fruit were stained with Wiesner reagent for detecting lignin. Pink staining indicates the presence of $p$-hydroxycinnamyl aldehyde end groups in lignin while brown staining indicates formation of $\mathrm{G}$ units (Panel a). Red staining (Panel $b$ ) shows the presence of syringyl units. Adjustments to magnification and illumination were made to allow optimal viewing of sections.
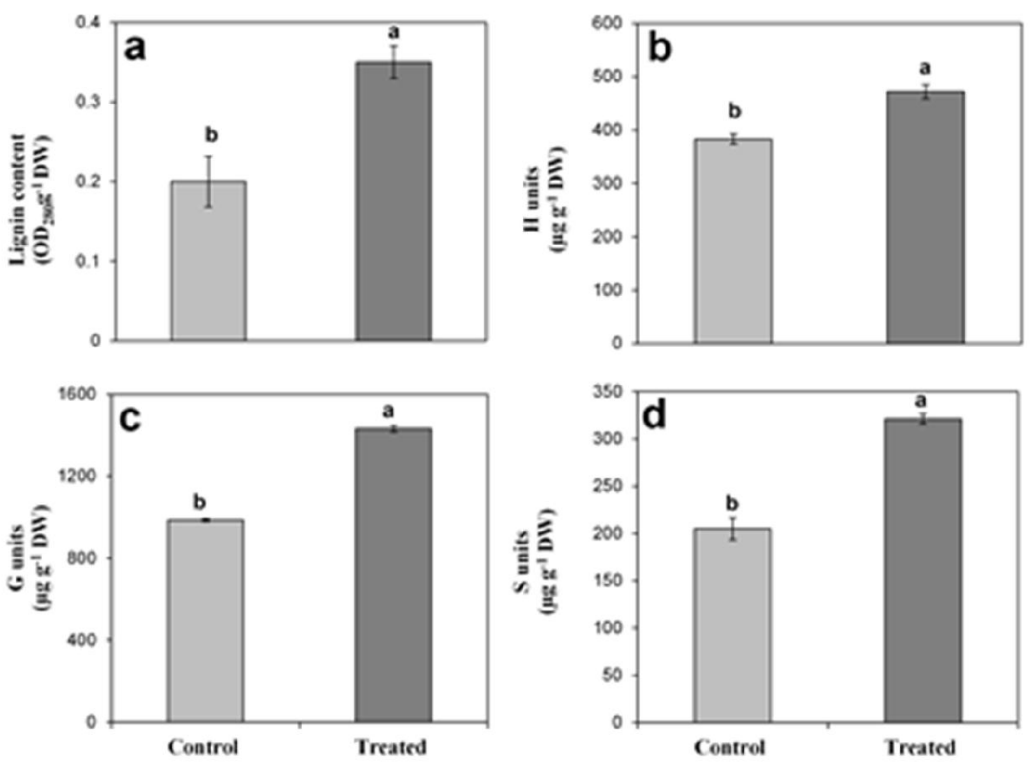

Fig. 4: Levels of lignins and their monomers in Control and Treated fruits of bitter gourd.

Means with different letters represent statistically significant differences between Control and Treated according to Student's $t$ test $(\mathrm{P} \leq .05)$.

\section{Discussion}

It is an established fact that well-nourished plants show better resistance/tolerance to pests and diseases compared to nutrient deficient plants since mineral elements constitute an integral part of their antioxidant defence machinery (Marschner, 2012). The melon fly susceptible bitter gourd showed significantly lower levels of $\mathrm{Ca}, \mathrm{Mg}, \mathrm{Mn}$ and $\mathrm{Cu}$ compared to the resistant chayote fruit Table (3). Hence, experiments conducted in the field by spraying bitter gourd plants with three concentrations of micronutrient solutions Table (1) containing the above four nutrients during the period of early fruit growth showed significantly lower rates of melon fly infestation coupled with 
higher cumulative fruit yield compared to control plants Table (4). From a nutritional perspective, micro nutrient deficiency leads to impaired production of defense compounds, accumulation of soluble carbohydrates and reduced lignification, all of which contribute to lowered pest resistance. Among the three levels of nutrient sprays employed in this study, it was evident that $T_{2}$ treatment was the best in terms of lower infestation and higher yield compared to control and the other two treatments. Hence, further experiments were carried out with only spraying $T_{2}$ treatment solution. It was evident from the study that the number of oviposition punctures, number of eggs laid, rate of pupation and the rate of adult emergence were significantly lower in $T_{2}$ treated plants compared to control Table (6). A notable aspect of the study was that treatment of bitter gourd fruits with $\mathrm{T}_{2}$ helped to restore the levels of $\mathrm{Ca}$ and $\mathrm{Cu}$ to the same level as in the resistant chayote while the tissue levels of $\mathrm{Mg}$ and $\mathrm{Mn}$ were also higher than that in control Table (5). This suggested a possible role for micronutrients in the development of host resistance against melon fly.

\section{Mineral elements enhance the levels of defence compounds in host plant}

The mode of interaction of mineral nutrients with insect pests is complex and depends on a number of external factors (Schumann et al., 2010). In a previous study, we had shown that susceptibility to melon fly in bitter gourd was the result of an imbalance between the rate of production of nsert Reactive oxygen species (ROS) and its elimination by antioxidant enzymes (Shivashankar et al., 2012). The present study revealed that mineral treatment with $T_{2}$ significantly enhanced the levels of the two antioxidant enzymes, SOD and POD, coupled with a significant reduction in CAT activity (Fig. 2). Since SOD enzyme has a role in detoxifying the excess $\mathrm{H}_{2} \mathrm{O}_{2}$, higher SOD activity in $\mathrm{T}_{2}$ Treated fruits indicated its ability to more rapidly neutralize the excess $\mathrm{H}_{2} \mathrm{O}_{2}$ compared to control. POD is known to promote covalent linking between lignin and cell wall polymers helping to increase the rate of lignification. Direct proof for the increased rate of lignification in $T_{2}$ Treated fruits was obtained in this study from histochemical staining of fruit tissues (Fig. 3) in which $T_{2}$ Treated plants displayed higher number of $\mathrm{G}$ units (brown) around the site of infestation suggesting the formation of highly cross-linked lignin while on the contrary, control fruits showed formation of S units (Red) showing its susceptible nature. Similar results were reported in pepper and tomato by Pomar et al. (2004) after $V$. dahliae inoculation. CAT activity is known to be crucial for maintaining the redox balance during oxidative stress (Willekens et al., 1997). Shim et al. (2003) showed that a fall in CAT activity under oxidative stress was related to the accumulation of salicylic acid which is believed to play a role in signalling plant resistance to herbivores (Ollerstam and Larsson, 2003). In a previous paper (Shivashankar et al., 2012), we had shown that bitter gourd accumulated lower level of salicylic acid compared to the melon fly resistant chayote. Hence, it was obvious that the reduced CAT activity in $T_{2}$ Treated bitter gourd fruits indicated its increased resistance to melon fly attack compared to control.

Further evidence for the higher rate of lignification in $\mathrm{T}_{2}$ Treated fruits came from data on the content of lignin and its monomers (Fig. 4). $\mathrm{T}_{2}$ Treated fruits showed significantly higher contents of lignin and monomers of $\mathrm{H}, \mathrm{G}$ and $\mathrm{S}$ compared to control fruits (Fig. 4). The S/G ratio in control was 0.207 while in $T_{2}$ Treated fruits, it was 0.224 . The increased ratio of syringyl to guaiacyl moieties is related to higher tissue maturity representing a higher frequency of cross-linking in lignin structure (Kishimoto et al., 2010). Thus, it was evident that the increased rate of lignification and cross-linking in $T_{2}$ Treated fruits aided in providing a more effective barrier to the entry of melon fly by inhibiting the penetration of insect stylets (Ingham et al., 1998) through the reinforcement of cell walls and thus contributed to development of increased resistance to melon fly infestation.

The levels of flavonoids Table (7) and phenolic acids Table (8) were significantly higher in $T_{2}$ Treated fruits compared to control. Past studies had shown that mineral elements influence host resistance through metabolic changes by way of synthesis of natural defense compounds such as, phytoalexins, antioxidants and flavonoids which provide protection against pests (Schumann et al., 2010). It was clear from Table (6) that there was a significantly higher rate of insect mortality in $T_{2}$ Treated fruits $(88.6 \%)$ compared to control $(14.4 \%)$ which was the result of a significantly lower oviposition, lower rate of pupation and slower rate of adult emergence. Phenolic acids are known to act as antifeedants, toxicants, ovicides and mitochondrial oxidation inhibitors in insects (Nishida, 2002) while flavonoids protect the plant against insect pests by influencing their growth, development and behaviour (Simmonds, 2003). Data shown in Table (7) showed that rutin and quercetin increased 
rapidly in $\mathrm{T}_{2}$ Treated fruits both of which are known to increase mortality of Lymantria dispar (Treutter, 2005) and tobacco armyworm (Spodoptera litura) in peanuts (Mallikarjuna et al., 2004). A number of insect species have been shown to be sensitive to flavonoid compounds in feeding tests (Treutter, 2005). Flavonoids are reported to reduce nutritive value and digestibility of plants and even act as toxins altering their palatability (Sosa et al., 2004). Among the phenolic acids, the rapid surge of gallic acid and syringic acid by 3-5 times in $\mathrm{T}_{2}$ Treated fruits compared to control Table (8) was helpful in suppressing the development of melon fly larvae while the upregulation of caffeic acid might act as feeding deterrent as reported by Bhattacharya and Chenchaiah (2007) in red gram against Spodoptera litura. Increased catechin content is known to increase antifeedancy through complexation. The 3-fold increase of chlorogenic acid in $\mathrm{T}_{2}$ Treated fruits compared to control was also helpful as it is a naturally occurring phenolic compound well known for its role in plant defence (Kirsten et al., 2009). The two-fold increase of salicylic acid (SA) in $T_{2}$ Treated fruit was significant as SA generates a wide range of responses involved in regulation of plant defence against biotic and abiotic stresses (Shah, 2003 and Shivashankar et al., 2015) through morphological, physiological and biochemical mechanisms (War et al., 2012). SA is, particularly known to be effective against piercing and sucking type of insect pests such as the melon fly. The rapid increase of antioxidant activity in $T_{2}$ Treated fruits compared to control (Fig. 2) was also in tune with the earlier reports wherein phenols and flavonoids were found to confer resistance to infestation through production of antioxidants (War et al., 2012). Thus, it was clearly evident from the present study that the resistance induced against melon fly by mineral supplementation during early growth of bitter gourd fruit was operating through the activation of antioxidant system involving synthesis of flavonoids, phenolic acids and antioxidant enzymes resulting in strengthening of the host plant to fight the infestation coupled with inhibition of oviposition, reduced pupation and increased mortality of melon fly insect.

\section{Conclusion}

The study established that resistance to melon fly in bitter gourd could be induced by micronutrient application although it is an inherited character. It was evident that expression of resistance to melon fly in bitter gourd was linked to the optimal levels of micronutrients. Supplementation of leaves and young developing bitter gourd fruits at 10,15 and 20 days after fruit set (DAF) with micronutrient formulation $\left(\mathrm{T}_{2}\right)$ consisting of $\mathrm{Ca}, \mathrm{Cu}, \mathrm{Mg}$ and $\mathrm{Mn}$ by spray application enhanced the levels of elements in fruit to optimum and significantly reduced the rate of melon fly infestation. The study proved that supplementation with mineral nutrients enhanced resistance to melon fly by inhibition of oviposition and increased mortality of melon fly insect through the activation of host antioxidant system involving synthesis of flavonoids, phenolic acids and antioxidant enzymes. Spray application of micronutrients to bitter gourd plants at the time of early fruit growth is a simple, safe, effective and eco-friendly approach to overcome melon fly infestation coupled with a significantly higher fruit yield. This approach could, therefore, be exploited for the successful field management of melon fly infestation in bitter gourd either singly or as a component of IPM strategy. This would not only minimize the use of hazardous plant protection chemicals but also aid in enhancing fruit yield, quality, food safety and nutritive value of fruits for human consumption.

\section{Acknowledgements}

The authors thank the Director, ICAR-IIHR, Bengaluru for providing facilities for this work. We are thankful to Dr H R Ranganath, Retired Principal Scientist for providing plant material for this study.

\section{Declaration of interest: None}

\section{Funder information}

This study was part of the approved research project of the institute and hence all financial support for the conduct of the research was provided by the institute. 


\section{References}

Aktar, M., W. D. Sengupta, and A. Chowdhury, 2009. Impact of pesticides use in agriculture: their benefits and hazards. Inter. Toxicol., 2(1): 1-12.

Beauchamp, C., and I. Fridovich, 1971. Superoxide dismutase: Improved assays and an assay applicable to acrylamide gels. Anal. Biochem., 44(1): 276-287.

Benzie, I. F., and J. J. Strain, 1996. The ferric reducing ability of plasma (FRAP) as a measure of 'antioxidant power': The FRAP assay. Anal. Biochem., 239(1): 70-76.

Bhattacharya, A.K., and K.C. Chenchaiah, 2007. Seed coat phenolic compound of red gram Cajanus cajan as chemical barrier in formulation of artificial diet of Spodoptera litura. Ann. Plant Pro. Sci., 15(1): 92-96.

Brand-Williams, W., M. E. Cuvelier, and C. Berset, 1995. Use of a free radical method to evaluate antioxidant activity. Leben Wissen Tech., 28(1): 25-30.

Christos, D., 2008. Role of nutrients in controlling plant diseases in sustainable agriculture. A review. Agro. Sus. Develop., 28(1): 33-46.

Dhillon, M.K., R. Singh, J.S. Naresh, and N.K. Sharma, 2005. Influence of physico-chemical traits of bitter gourd, Momordica charantia L. on larval density and resistance to melon fruit fly, Bactrocera cucurbitae (Coquillett). J. App. Entomol., 129(7): 393-399.

Doster, M.A., and P.M. Bostock, 1988. Quantification of lignin formation in almond bark in response to wounding and infection by Phytophthora species. Phytopathol., 78(4): 473-477.

Goncalves-Alvim, S.J., R.G. Collevatti, and G.W. Fernandes, 2004. Effects of genetic variability and habitat of Qualea parviflora (Vochysiaceae) on herbivory by free-feeding and gall-forming Insects. Ann. Bot., 94(2): 259-268.

Gupta, N., S. Debnath, S. Sharma, P. Sharma and J. Purohit, 2017. Role of nutrients in controlling the plant diseases in sustainable agriculture. In Agriculturally Important Microbes for Sustainable Agriculture, eds. V. Meena, P. Mishra, J. Bisht, A. Pattanayak, Singapore, Springer.

Hossain, M.A., P. Pukclai, A. Jaime, S. Teixeira da and F. Masayuki, 2012. Molecular mechanism of heavy metal toxicity and tolerance in plants: central role of glutathione in detoxification of reactive oxygen species and methylglyoxal and in heavy metal chelation. J. Bot., 37: 872-875.

Huber, D., V. Römheld, and M. Weinmann, 2012. Relationship between nutrition, plant diseases and pests. In Mineral nutrition of higher plants, ed. P. Marschner, 283-298. London Academic Press.

Ingham, L.M., M.L. Parker, and K.W. Waldrom, 1998. Peroxidase: changes in soluble and bound forms during maturation and ripening of apples. Physiologia Plant., 102(1): 93-100.

Jackson, M.L., 1973. Soil chemical analysis. Prentice Hall of India Private Limited, New Delhi, India. 498.

Jones Jr, J.B., B. Wolf, and H.A. Mills, 1991. Plant analysis hand book. Micro-Macro Publishing Inc., Athens, 213.

Kim, D. O., O. K. Chun, Y. J. Kim, H. Y. Moon, and C. Y. Lee. 2003. Quantification of polyphenolics and their antioxidant capacity in fresh plums. J. Agric. Food Chem., 51(22): 6509-6515.

Kirsten, A. L., M. Federica, H.C. Young, V. Robert, and G.L. K. Peter, 2009. Identification of chlorogenic acid as a resistance factor for thrips in Chrysanthemum. Plant Physiol., 150(3): $1567-1575$.

Kishimoto, T., W. Chiba, K. Saito, K. Fukushima, Y. Uraki, and M. Ubukata, 2010. Influence of syringyl to guaiacyl ratio on the structure of natural and synthetic lignins. J. Agric. and Food Chem., 58 (2): 895-901.

Lima, R.B., V.H. Salvador, W.D. dos Santos, G.A. Bubna, A. Finger-Teixeira, A.R. Soares, R. Marchiosi, M. de Lourdes, L. Ferrarese, and O. Ferrarese-Filho, 2013. Enhanced lignin monomer production caused by cinnamic acid and its hydroxylated derivatives inhibits soybean root growth. PLoS One. 8. e80542.

Lowry, O. H., N. Rosebrough, A. Farr, and R. Randall, 1951. Protein measurement with the FolinPhenol reagent. J. Biol. Chem., 193 (1): 265-275. 
Luck, H., 1965. Catalase. In Methods of Enzymatic Analysis, ed. H.U. Bergmeyer, 885-894. New York, Academic Press.

Mallikarjuna, N., K.R. Kranthi, D.R. Jadhav, S. Kranthi, and S. Chandra, 2004. Influence of foliar chemical compounds on the development of Spodoptera litura in interspecific derivatives of groundnut. J. App. Entomol., 128 (5): 321-328.

Marschner, H., 2012. Marschner's mineral nutrition of higher plants, $3^{\text {rd }}$ ed. 672pp. London, Academic Press.

Narayanan, E.S., 1953. Seasonal pests of crops. Indian Farming. 3, 8-11, 29-31.

Nishida, R., 2002. Sequestration of defensive substances from plants by Lepidoptera. Ann. Rev.Entomol., 47: 57-92.

Ollerstam, O., and S. Larsson, 2003. Salicylic acid mediates resistance in willow Salix viminalis against the gall midge, Dasineura marginemtorquens. J. Chem. Ecol., 29(1): 163-174.

Panse, V. G., and P. V. Sukhatme, 1978. Statistical Methods for Agricultural Workers. Indian Council of Agricultural Research, New Delhi, India. 108.

Pomar, F., M. Novo, M.A. Bernal, F. Merino, and A.R. Barcelo, 2004. Changes in stem lignins (monomer composition and crosslinking) and peroxidase are related with the maintenance of leaf photosynthetic integrity during Verticillium wilt in Capsicum annuum. New Phytol., 163, 111-123.

Pretty, J., and Z.P. Bharucha, 2015. Integrated pest management for sustainable intensification of agriculture in Asia and Africa. Insects 6(1):152-182.

Saroop, S., S.V. Chanda, and Y.D. Singh, 2002. Changes in soluble and ionically bound peroxidase activities during Brassica juncea seed development. Bul. J. Plant Physiol., 28(3-4): 26-34.

Shah, J., 2003. The salicylic acid loop in plant defense. Curr. Opin. Plant Bio., 6: 365-371.

Shim, I. S., Y. Momose, A. Yamamoto, D. W. Kim, and K. Usui, 2003. Inhibition of catalase activity by oxidative stress and its relationship to salicylic acid accumulation in plants. Physiologia Planta., 39(3): 285-292.

Shivashankar, S., M. Sumathi, and H.R. Ranganath, 2012. Roles of reactive oxygen species and antioxidant systems in the resistance response of chayote fruit (Sechium edule) to melon fly [Bactrocera cucurbitae (Coquillett)]. J. Hort. Sci. Biotech., 87, 391-397.

Shivashankar, S., M. Sumathi, N. K. Krishnakumar, and V. K. Rao, 2015. Role of phenolic acids and enzymes of phenylpropanoid pathway in resistance of chayote fruit (Sechium edule) against infestation by melon fly, Bactrocera cucurbitae. Ann. App. Biol., 166(3): 420-433.

Silva, A.A., E. M. Varanda, and A. C. Primavesi, 2005. Effect of the inherent variation in mineral concentration of alfalfa cultivars on aphid populations. Bragantia 64: 233-239.

Simmonds, M.S., 2003. Flavonoid-insect interactions: Recent advances in our knowledge. Phytochem., 64: 21-30.

Singleton, V. L., and J. A. Rossi, 1965. Colorimetry of total phenolics with phosphomolybdicphosphotungstic acid reagents. Amer. J. Eno. Viti., 16: 144-158.

Sosa, T., N. Chaves, J.C. Alias, J.C. Escudero, F. Henao, and C. Gutierrez-Merino, 2004. Inhibition of mouth skeletal muscle relaxation by flavonoids of Cistus ladanifer L., A plant defense mechanism against herbivores. J. Chem. Ecol., 30 (6): 1087-1101.

Schumann, A.W., T. Vashisth, and T. M. Spann, 2010. Mineral nutrition contributes to plant disease and pest resistance. University of Florida, IFAS Extension bulletin, http://edis.ifas.ufl.edu.

Treutter, D., 2005. Significance of flavonoids in plant resistance and enhancement of their biosynthesis. Plant Biol., 7(1): 581-591.

War, A. R., G. P.Michael, A.Tariq, A. B. Abdul, H. Barkat, I. Savarimuthu, and C. S. Hari, 2012. Mechanisms of plant defense against insect herbivores. Plant Signal. Behav., 7(10):1306-1320.

Willekens, H., S. Chamnongpol, M. Davey, R. M. Schraudne, and C. Langebartels, 1997. Catalase is a sink for $\mathrm{H}_{2} \mathrm{O}_{2}$ and is indispensable for stress defense in $\mathrm{C}_{3}$ plants. EMBO J., 16 (16):48064816. 